\title{
Monarchia, imperio universal y patronazgo regio. Los Austrias mayores, el pontificado, Dante y Gattinara sobre la construcción de la auctoritas católica*
}

Simone Fracas ${ }^{* *}$

Recibido el 7 de diciembre de 2018; aceptado el 2 de abril de 2019

\section{RESUMEN}

Este artículo trata sobre la construcción de la idea imperial de Carlos V y de Felipe II a partir de las concepciones del poder desarrolladas por Dante Alighieri en su Monarchia, y retomadas por Mercurino Arborio di Gattinara, el genuino gran canciller de Carlos V. Paralelamente, el artículo revisa la evolución y expansión de los derechos de Patronazgo desde la época de los Reyes Católicos hasta finales del siglo XVI, para argumentar que la Corona castellana acabó por asumir rasgos cesaropapistas no muy distintos de los del sistema eclesial anglicano.

Palabras clave: Imperio español, patronazgo, Nueva España, papado, Bulas Alejandrinas.

* El artículo se desarrolló gracias al Programa de Becas Posdoctorales en la Universidad Nacional Autónoma de México (UNAM), bajo la asesoría académica de la doctora Patricia Escandón (CIALC-UNAM). Agradezco a los colegas doctora María Guevara, doctor Rossend Rovira Morgado y maestro Eduardo Ayala Tafoya la lectura, discusión y sugerencias a este texto.

** Centro de Investigaciones sobre América Latina y el Caribe (CIALC), UNAM, Ciudad de México, México, correo electrónico: fracas.simone@gmail.com.

ORCID: https://orcid.org/0000-0001-8740-6895 


\title{
Monarchia, Universal Empire and Regal Patronage. Habsburg Spain, Roman Pontiffs, Dante and Gattinara on the construction of Catholic auctoritas
}

\begin{abstract}
This paper is about Charles V and Philip II construction of imperial concept, founded in a solid tradition that goes from Dante Alighieri's Monarchia to the writings of Mercurino Arborio da Gattinana, the very Grand Chancellor of Charles V. Simultaneously, the papes deals with the issue of the Right of Patronage. Its origins in the age of Reyes Católicos and its further expansions at the end of 16th Century are investigated in order to propose how the Castilian crown developed cesaropapist features not much different from the Anglican ecclesial system.

Key words: Key words: Empire, patronage, New Spain, pope, Alexandrine Bulls of Donation.

I

廿 $\mathrm{n}$ el primer tercio del siglo XVI, Europa presenció una insólita concentración de vastos y heterogéneos territorios en manos de un solo heredero de casa real: Carlos de Habsburgo. Digamos que por testamentaría, en 1506 Carlos recibió de su abuela materna, Isabel la Católica, los reinos de Castilla y León, con los demás territorios a ellos anexos (a pesar de que reinó en ellos a través de su madre, Juana I de Castilla, hasta el fallecimiento de ésta). De su padre, Felipe el Hermoso, heredó la posesión del Ducado de Borgoña, de los Países Bajos y de Austria; tras la muerte de su abuelo materno, Fernando, en 1516, le vino la posesión de Aragón y del Reino de Nápoles, es decir, de la totalidad de la parte meridional de la península italiana. Finalmente, en 1522 por la herencia de su abuelo paterno, Maximiliano I, fue reconocido como Sacro romano emperador.

En febrero de 1525, cuando las tropas de Carlos derrotaron a las de Francisco I de Francia en Pavía, el sueño del encumbramiento de un emperador universal cristiano pareció materializarse porque el tratado de paz de Madrid del año siguiente decretó la hegemonía de los Habsburgo en Italia. Indiscutiblemente, hubo en ello una visión providencialista, pues se había emprendido una guerra justa contra el rey galo que, según Carlos, terminó cuando "Dios trajo al rey de Francia mi enemigo a mi manos". 1
\end{abstract}

1 Sandoval, Historia de la vida y hechos del emperador Carlos V, p. 122. Russell, The Just War in the Middle Ages. Keen, The Laws of War in the Late Middle Ages, pp. 156-188. 
La aspiración de una monarquía lo bastante fuerte para reunir bajo su control a toda la cristiandad no se fundamentaba únicamente en una arbitraria voluntad de dominio nominal; después de 1526, la monarchia universalis tuvo que arrostrar problemas geopolíticos y sociales definitivamente perentorios. Por un lado, estaba la amenaza turca que parecía extenderse rápidamente por todo el Mediterráneo y, por el otro, había que encarar el creciente éxito de la Reforma protestante. En consecuencia, la nueva "cruzada" no se dirigía ya a Tierra Santa, sino a Europa misma, para defenderla a dos frentes: de los infieles y de los heréticos. A la empresa contribuyó el papa León X con la expedición de diversas bulas: unas que establecían la tregua entre los "verdaderos" príncipes cristianos y otra más, la Exurge Domine (1520), que censuraba las tesis de Lutero y disponía la confiscación de sus obras. ${ }^{2}$

Junto a esta situación preocupante surgía una más que inquietaba a las coronas europeas: el alarmante crecimiento del poderío español. Los más intranquilos a este respecto eran el pontífice romano y el Rex christianissimus de Francia, pues para retener su papel protagónico en el teatro europeo era imperativo que el papado siguiera siendo la máxima autoridad - al menos en materias espirituales-y en cuanto al soberano francés, ya tenía por entonces aspiraciones de hacer de su reino una monarchia universalis. Por ese mismo temor, el papa Clemente VII formaría la Liga de Cognac que pretendía contener la expansión hispánica en Italia aunque, como se sabe, todo terminó para él en un estrepitoso fracaso, con la invasión y el ulterior Sacco de Roma. ${ }^{3}$ Por su lado, Francisco I de Francia rompería la alianza con el pontificado para constituir una coalición con el imperio otomano de Solimán, lo que inauguró una nueva fase de guerras contra los Habsburgo. ${ }^{4}$ En suma, parecía imposible que se impusiera la paz entre los soberanos europeos y el factor determinante era, sin duda, el imparable ensanchamiento del poder de la casa real austriaca.

El justificado desasosiego de los rivales de Carlos no se cifraba sólo en su hipotético acaparamiento de territorios, sino en el de otros derechos o prerrogativas que tenían profundas implicaciones. Así, con los reinos alema-

2 Lesaffer, Peace Treaties and International Law in European History, p. 12. Hillerbrand, "Martin Luther and the Bull Exsurge Domine", p. 109.

3 Para una mirada general cfr. Firpo, "Il sacco di Roma e la sua eredità". Las conexiones entre el hecho histórico del Sacco y sus interpretaciones apocalípticas (imperialismo apocalíptico) han sido analizadas en Firpo, Il Sacco di Roma del 1527. Tra profezia, propaganda politica e riforma religiosa. Para un análisis de la recepción y de las representaciones (literarias y visuales) del Sacco entre los contemporáneos, cfr. Vidal, "Una revisione delle tesi di André Chastel su alcune rappresentazioni contemporanee del Sacco di Roma (1527)", pp. 275-312.

4 Knecht, Renaissance Warrior and Patron. Black, European Warfare, 1494-1660. Mallett y Shaw, The Italian Wars, 1494-1559. 
nes, Carlos heredó formalmente el título de emperador, es decir el armazón ideológico que lo hacía depositario de la legitimidad del populus romanus; además, su sólida presencia en Italia era decisiva para apoyar un proyecto que asumía la "prolongación" del antiguo Imperio romano. Por otro lado, el Ducado de Borgoña confería también a su poseedor el título de Gran Maestro del Toisón de Oro, una dignidad casi "celestial" en la construcción de la imagen retórica y el aparato iconográfico del nuevo emperador. ${ }^{5} \mathrm{Y}$, finalmente, junto con la herencia de los Reyes Católicos de los reinos españoles y sus anexos iban aparejados los privilegios del llamado Patronazgo regio, una suculenta concesión de las Bulas Alejandrinas y de otras posteriores que dotaba a los soberanos de Castilla de amplísimas facultades sobre la Iglesia. Todo ello relacionado con el surgimiento y conquista del Nuevo Mundo, un dominio que ya lucía sin duda como otro imperio allende el Atlántico. ${ }^{6}$

\section{II}

El capital territorial y simbólico que Carlos de Habsburgo había acumulado al comienzo del siglo XVI hizo revivir con fuerza la tradicional disputa entre imperio y papado por el control de la cristiandad, querella que se venía arrastrando desde el medioevo.

En la Edad Media la percepción era que los territorios que pertenecían al antiguo Imperio romano de Occidente - a pesar de su caída en 476- seguían formando una unidad sustancial, una continuidad ideológica reunida bajo el sello de un nebuloso cristianismo que, en consecuencia, se denominaba Res Publica Christiana. Se asumía que el conjunto de pueblos que lo formaban era, ante todo, una comunidad que, pese a sus diferencias regionales, compartía una misma mentalidad en la que los ideales cristianos guiaban los aspectos sociales, políticos y económicos. Aunque lo cierto es que se trataba de algo más que de una mentalidad, pues la influencia de los ideales cristianos se plasmaba en la vinculante ley canónica, un sistema legal originado en la doctrina teológica cristiana. En ella, los principios morales del cristianismo se concretaban en leyes que debían ser respetadas y que determinaban el funcionamiento de la sociedad entera.

Tras la crisis del siglo V, el papado se autoerigió como la suprema autoridad de la Christianitas y desarrolló una retórica de poder para fincar su

5 Rosenthal, "The Invention of the Columnar Device of Emperor Charles V" pp. 198-230. Cañeque, "Imaging the Spanish Empire: The Visual Construction of Imperial Authority" pp. 29-68. Tanner, The Last Descendant of Aeneas, pp. 146-161.

6 Frankl, "Imperio particular e Imperio Universal", pp. 99-138. 
preminencia en el orbe católico. A este respecto, la teoría de las dos espadas ${ }^{7}$ que propusiera el papa Gelasio I (492-496) fue una de las aportaciones más descollantes, pues planteaba la creación divina de dos poderes para el gobierno de los hombres: el temporal y el espiritual. Y aun reconociendo el pontificado la autoridad del primero y su importancia para la salud de la sociedad, la auctoritas espiritual seguía siendo jerárquicamente superior, es decir, más alta e importante que la potestas imperial.

En el bando opuesto, el del poder temporal, primero el Imperio Carolingio y luego el Romano-Germánico pretendieron revivir para sí los títulos y prestigio de la antigua Roma imperial. Ambos se asumieron como institu-

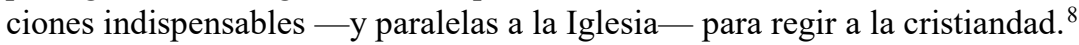
Y en este sentido, rivalizaron con las pretensiones pontificias de supremacía.

De las respectivas posturas de Iglesia e imperio se desprende lo complejo del escenario de poder y su doble alma; así que no extraña que los tiempos de pugna abierta entre una y otro se alternaran periódicamente con temporadas de apoyo mutuo.

Este conflicto - enraizado en las teorías imperiales desarrolladas en la época romana- se origina a partir de diferentes especulaciones ${ }^{9}$ que aspiraban a resolver un dilema: ¿Cuál es la cabeza de la sociedad cristiana? A partir de la hermenéutica bíblica, de la cual vienen los rasgos teleológicos y escatológicos del imperio y de la interpretación del profeta Daniel sobre el sueño de Nabucodonosor, ${ }^{10}$ se armó la tradicional doctrina de la translatio imperii según la cual, originalmente, el oficio imperial es únicamente una función-emanación de la Iglesia, con lo que el emperador actuaría sólo bajo el mandato del papa. Por otro lado, el desarrollo medieval de la ley romana,

7 Decretum magistri Gratiani (1879). Ed. Lipsiensis secunda post Aemilii Ludovici Richteri curas ad librorum manu scriptorum et editionis Romanae fidem recognovit et adnotatione critica instruxit Aemilius Friedberg. Leipzig. Distinctio XCVI, C. X. Auctoritas sacra Pontificum et regalis potestas huius mundi gubernacula regit. $<$ http://geschichte.digitalesammlungen.de/decretum-gratiani/kapitel/dc_chapter_1_1042>, consultado el 25 de septiembre de 2016.

8 Muldoon, Empire and Order, pp. 30, 37, 64.

9 Me ocupo aquí únicamente de la tradición latina-europea. Pero no me parece superfluo indicar que la misma polémica que se produjo entre los herederos del Imperio Romano de Occidente (reinos barbáricos, papado, dinastías francesas y alemanas) tuvo su contrapartida en los del Imperio Romano de Oriente, es decir los Basileus bizantinos. En el desarrollo del ideal imperial en Oriente: "Constantinople was manifestly the greatest city in the world, and all those gentiles or barbarians who had challenged the might of the Empire, Persians, Arabs, Slavs or Bulgarians, had been beaten back. The claims of the Holy Roman Emperors in Germany were regarded by the true emperors in Byzantium with angry contempt or amused disdain". Cfr. Nicol, The Last Centuries of Byzantium, p. 73 y el texto de Angelov, Imperial Ideology and Political Thought in Byzantium.

10 Daniel, 2-26, 45. 
que contenía la idea de un emperador como señor del mundo (dominus mundi), sustentaba y justificaba la noción de un poder independiente al pontificado. La misma ceremonia de coronación imperial, tradición inaugurada por el papa León III y Carlomagno el día de la Navidad de 800, se interpretaba de distintos modos según los bandos: para los partidarios de la supremacía pontificia podía entenderse como evidencia de la superioridad del papa, puesto que creaba de facto un emperador, en tanto que para los que favorecían al imperio no se trataba más que de un simple símbolo ceremonial que no creaba ex nihilo, sino que sólo celebraba públicamente al emperador.

La referencia medieval más importante que se ocupa de las relaciones entre estas dos entidades es Graciano, teólogo y jurista, que entre los siglos XII-XIII revolucionó la teoría del derecho canónico con la publicación del Decretum. ${ }^{11}$ Él fue el primer tratadista en dedicarse no únicamente al análisis político de los textos clásicos y patrísticos, sino que se dio a la empresa de buscar, a través de la práctica legal, soluciones empíricas a los problemas de la Iglesia de su época. Como canonista, su tarea puntual fue transformar los principios morales cristianos en leyes comunes y compartidas por toda la cristiandad. En este contexto, las dinámicas relacionales entre poder secular y poder espiritual empezaron a mudar radicalmente. El Decretum es una fuente inestimable para reconstruir el proceso histórico del conflicto, pues se elaboró a partir de una recopilación de las fuentes, de un acopio de los documentos que testimoniaban los precedentes más importantes de la política del papado. Y a través de ellos podemos esbozar el desarrollo de un lenguaje de autoridad que marcó la retórica pontificia, cuyo vértice llega sin duda en la época de Bonifacio VIII. En la bula Unam Sanctam (1302), ápice del desarrollo teocrático de las teoría pontificias, ${ }^{12}$ se decreta clara e incuestionablemente que las dos espadas, espiritual y temporal, son entregadas por Dios únicamente para la defensa de la única y verdadera Iglesia; ${ }^{13}$ en consecuencia, quien desconociera la autoridad pontificia no sería considerado miembro de la comunidad y su poder carecería de todo fundamento.

Acaso, como han dicho algunos historiadores, la pretensión política del papado se basaba en la confusión, tal vez deliberada, entre lo que Cristo dijo

11 Es interesante que este compendio, a través del cual Graciano se propuso resolver las dificultades de la theologia practica externa, nunca fue reconocido por la Iglesia como códice oficial, no obstante de facto llegó a ser el tratado más utilizado y difundido de la cristiandad.

12 Bula, Unam Sanctam, 18 de noviembre de 1302: "Uterque ergo est in potestate ecclesiae, spiritualis scilicet gladius et materialis. Sed is quidem pro ecclesia, ille vero ab ecclesia exercendus, ille sacerdotis, is manu regum et militum, sed ad nutum et patientiam sacerdotis. Oportet autem gladium esse sub gladio, et temporalem auctoritatem spirituali subjici potestati”. <https://la.wikisource.org/wiki/Unam_sanctam>, consultado el 25 de septiembre de 2016.

13 Logan, A History of the Church in the Middle Ages, p. 262. 
a Pedro y lo que los herederos de Pedro acumularon en el largo trayecto histórico de la Iglesia, ${ }^{14}$ pero también es cierto que el alcance del poder político papal sobre los dominios temporales fue más virtual que real. Menos discutible es el alcance de la retórica pontificia en el ámbito de la legitimación del poder, y también la cuestión de si la absolutización del lenguaje que desarrolló la monarquía papal tendía a esconder que la retórica narrativa sobrepasó la realidad. ${ }^{15}$

Como haya sido, a partir del siglo XII, los juristas y tratadistas al servicio de los emperadores empezaron a elaborar una teoría legal cimentada en el hecho que el papado no tenía prerrogativa alguna en la elección del emperador, considerado a su vez señor del mundo entero. ${ }^{16} \mathrm{El}$ texto más importante en este trayecto, es sin duda, el Monarchia de Dante Alighieri, escrito entre 1310 y 1313 en el ámbito de la disputa entre Güelfos y Gibelinos. Lo que a primera vista parece ser únicamente una excelsa recopilación de la tradición legal romana y de sus modificaciones, operadas sobre todo por los juristas Bartolo y Baldo ${ }^{17}$, es importante porque conecta y subraya con mayor fuerza las conexiones entre la tradición legal romana y la cristiana.

La ley romana era considerada la única fuente de salud de una república, porque sólo compartiendo una ley común la humanidad había sido capaz de poner fin a las guerras y establecer la paz en la época dorada del Imperio romano. Es evidente que una monarquía unificada hubiera sido la única institución que habría garantizado la uniformidad de la ley y de su aplicación. Según la tradición romana, la lex regia, que era prerrogativa del emperador, de hecho provenía "directamente" del pueblo romano, que teóricamente transfería su propiedad de auto-gobernación, sin intermediarios, al mismo emperador. Esta teoría se reveló como una poderosa herramienta de legitimación de los emperadores cuando se añadió a una contraparte de derivación cristiana. ¿No es en definitiva el mismo Jesús

14 De la Hera, "Evolución de las doctrinas sobre las relaciones entre la Iglesia y el Estado", p. 266.

15 "Innocent is a test case for papal monarchy, because no pope in history was so fitted by talent and circumstances to make it workable. The language became progressively more absolute, but rhetoric had outstripped reality. The curia could respond to outside pressure, exert moral influence, and enlist the sympathy of interested parties; but only rarely could it command". Cfr. Morris, The Papal Monarchy, p. 451.

16 Digesta Iustiniani Augusti, 14.2.9, Ego orbis terrarum dominus sum, lex autem maris, lege Rhodia de re nautica res iudicetur, quatenus nulla lex ex nostris ei contraria est. $<$ http://droitromain.upmf-grenoble.fr/Corpus/d-14.htm\#2>, consultado el 25 de septiembre de 2016.

17 Cabe señalar que, si en efecto los canonistas medievales Bartolo y Baldo produjeron una teoría fundamentalmente teocrática para legitimar el imperio, jamás indicaron que el oficio del emperador tuviera una posición jerárquica superior a la del papa, cuya dignidad carece absolutamente de rivales. 
Cristo quien confirió al imperio dignidad divina? ${ }^{18}$ Además, si Dios es quien concede al ser humano el derecho y las leyes, cuando el pueblo transfiere dicho poder al monarca se puede decir que éste ostenta un poder divino. Pocos años después, y en el contexto de la pugna entre Felipe IV de Francia y el papa Bonifacio VIII, Marsilio da Padova en sus Defensor pacis (1324) y Defensor minor (1342), se pronunciaría también a favor de que el origen de las leyes radicaba en el populus. ${ }^{19}$

Pero, volviendo a Dante Alighieri, su Monarchia ha de considerarse una obra innovadora porque aunque el texto ciertamente recogió tradiciones legales, jurídicas, políticas y teológicas precedentes, su mayor mérito radicó en la elaboración de una densa, brillante y novedosa teoría, según la cual, el emperador no sólo debía su poder a la elección directa de Dios - con lo que su investidura no devenía un mero ofício de la Iglesia- sino que, además, la institución imperial resultaba superior a la pontificia. El concepto del imperio se conectaba con la extensión virtualmente ilimitada de la cristiandad, de manera que su monarchia temporalis, que era el imperio, se sustraía de facto a la supremacía del papado. En las primeras páginas, Dante subrayaba los puntos principales de su análisis que, en definitiva, fue escrito para contestar tres preguntas: ¿La monarquía es necesaria para el bienestar del mundo? ¿El pueblo de Roma asumió la función del monarca? ¿El propio monarca recibe su autoridad directamente de Dios o de su vicario o ministro? ${ }^{20}$

Al plantear sus teorías, el autor se ocupa de las relaciones entre los poderes y es allí donde construye la más extensa y erudita crítica a las pretensiones del pontificado sobre el imperio. Asume primero la teoría clásica de los canonistas según la cual, papado e imperio existen y se relacionan como el sol y la luna; luego, de las Sagradas Escrituras extrae las citas que subrayan la importancia de la monarquía universal y critica aquéllas que parecen conferir al pontífice cualquier supremacía sobre el poder secular. A continua-

18 de Dios.

19 De cualquier manera, las ideas de Marsilio a propósito del imperio, de la jerarquía de los cuerpos sociales del origen del derecho y de las relaciones entre los varios componentes de la sociedad no fueron desarrolladas en escritos ni recibidas de forma sistemática, según lo demuestran algunos estudios específicos. Cengarle, "Potestas condendi leges: The Erosion of a Civic Prerogative under the Pressure of Princely Rule", pp. 113-128, investiga la erosión de las prerrogativas civiles (pertenecientes al populus) por parte del poder del príncipe basándose en fuentes del norte de Italia (estatutos cívicos y en textos jurídicos). Los problemas internos del corpus de Marsilio son estudiados por Nederman, "From Defensor Pacis to Defensor Minor: The Problem of Empire in Marsiglio of Padua", pp. 313-329, Nederman, Lineages of European Political Thought: Explorations along the Medieval/Modern Divide from John of Salisbury to Hegel, pp. 160-176 y Sigmund, "The Influence of Marsilius of Padua on XVth-Century Conciliarism", pp. 392-402.

20 
ción, pone en tela de juicio la validez de la Donación de Constantino desde el punto de vista político: el emperador no tenía el derecho de privarse de las prerrogativas de su oficio y el papado no tenía el derecho de aceptarlas. Finalmente, aborda la doctrina de las dos espadas. Si la humanidad tiene dos jefes es porque está llamada a la felicidad, en este mundo y en el otro. Naturalmente, ello significa que, en este mundo, la autoridad del pontífice es estrictamente espiritual, es decir, que no puede entrometerse en los asuntos temporales que son prerrogativa de los emperadores.

Rasgo sumamente importante y novedoso en sus planteamientos es la noción de humana civilitas, ${ }^{21}$ que retomaba la teoría política griega y la juntaba con las doctrinas de la cristiandad. En consonancia con Aristóteles, la civilitas era para Dante la forma a través de la cual el ser humano se organizaba en colectividad, la única institución que permitía a cada individuo lograr la perfección de la especie, es decir, desarrollar al máximo grado las capacidades intelectivas del hombre. Esta teleología autoriza en la obra un proceso de acercamiento al instrumento singular que hacía posible que el hombre alcanzara dicha meta: la paz universal, que para Dante es finalmente un medio. Así, el fin principal de la monarquía universal es el mantenimiento de esta paz, lo que sólo se alcanza con un monarca absolutus, capaz de resolver los conflictos entre los demás príncipes y, al mismo tiempo, de cancelar las presunciones de cualquier ministro espiritual o jurista canónico que pretendiese legitimar la supremacía de la Iglesia sobre el poder secular.

\section{III}

A la luz de lo hasta aquí planteado, echemos un vistazo a la historia antigua de la península ibérica, en la advertencia de que a las dinámicas ya presentadas tendremos que añadir dos componentes adicionales: el primero, el fuerte proselitismo del catolicismo local y el segundo, el desarrollo autónomo del ideal imperial.

En cuanto a lo primero, cierta historiografía atribuye al catolicismo de la época visigótica un rasgo de unidad, por más que esta etapa hubiera estado signada por la lucha entre las diferentes confesiones cristianas - especialmente en contra del arrianismo - y por las tensiones que ocasionaba la centralidad del poder político. ${ }^{22}$ Paulatinamente (y gracias sobre todo

21 Muldoon, Empire and Order, p. 93. Passerin d'Entrèves, Dante as a Political Thinker, pp. $44,47$.

22 Una fuente útil a la historiografía moderna por la crítica a estos planteamientos es: la Historia Wambae regís de Julián de Toledo. Cfr. Monumenta Germaniae Historica, Scriptores rerum Merovingicarum, vol. V, pp. 486-535. http://www.dmgh.de/de/fs1/object/goToPage/ 
a Leovigildo), el arrianismo empezó a ser arrinconado, luego tildado de herejía y finalmente derrotado. Unos historiadores atribuyen este proceso a la utilidad que los reyes visigodos vieron en el cristianismo para unificar reinos que, de otra suerte, estarían divididos, ${ }^{23}$ anticipando con ello una visión que, más tarde, sería distintiva de ulteriores períodos históricos.

Si la unidad doctrinal del III Concilio de Toledo se planeó por razones de oportunismo político que pretendía evitar la violencia, ${ }^{24}$ el componente confesional más "militante" del cristianismo, originariamente propio de los reinos del centro-norte de España, llegó a ser un poderosísimo instrumento en el proceso de formación de la monarquía "nacional" unificada. El cristianismo fue el único elemento que pasó por ser una "auténtica" característica tradicional y común a toda la península antes de la invasión musulmana, con lo que el proselitismo y la pretensión de universalidad del Islam provocaron una renovación del sentimiento religioso empuñado como arma de conquista. La construcción de una idea de hispanidad fue fundada principalmente en la eliminación de todo elemento cultural "ajeno" a los ideales cristianos y tal unificación, llevada a cabo entre 711 y 1492, recibió el nombre de Reconquista. Si por un lado el doloroso proceso histórico creó los reinos de Castilla y León, Aragón y Navarra a través de la conjunción de los pequeños dominios cristianos que sobrevivieron a la dominación musulmana, por el otro produjo una "consustanciación entre el cristianismo y el modo de ser y entender España, que llegó a resultar propia de los pueblos hispánicos, y que les acompañó durante toda la Edad Moderna". ${ }^{25} \mathrm{Si}$ antes la "impermeabilidad" de la sociedad hispánica al mestizaje cultural era algo artificioso y bastante relativo, como lo testimonian los numerosos ejemplos de intersecciones culturales, después de 1492 se transformaría en un riguroso acto político.

Las repercusiones de la Reconquista en la cultura hispánica fueron tan fuertes que algunos historiadores, incluso en el marco de una polémica historiográfica sobre la validez de su significado, llegaron a llamarla "la llave de

bsb00000752.html?pageNo=486\&sortIndex $=010 \% 3 \mathrm{~A} 020 \% 3 \mathrm{~A} 0005 \% 3 \mathrm{~A} 010 \% 3 \mathrm{~A} 00 \% 3 \mathrm{~A} 00$, consultado el 25 de septiembre de 2016. Nueva edición e traducción e Martínez Pizarro, The Story of Wamba.

23 Collins, “¿Dónde estaban los arrianos en el año 589?”, pp. 211-222. Collins, Visigothic Spain, p. 66. García Villada, Historia Eclesiástica de España, vol. II. pp. 59-60.

24 Para una reflexión sobre la complejidad de las relaciones entre las confesiones cristianas en este período puede ser provechoso consultar las actas conciliares retomadas en Martínez Diez y Rodríguez, La colección canónica hispana. La fuerte presencia del catolicismo céltico en esta época es prueba de que los cristianismos ofrecían variantes y hace dudar de la existencia de una confesión uniforme en la Península. Entre muchos estudios que se ocupan del asunto, puede consultarse: Fernández Conde, "Bretones o británicos en Asturias", pp. 463-472.

25 De la Hera, "La Monarchia Catholica española", p. 666. 
Historia de España". ${ }^{26}$ No hablamos sólo de un proceso militar, ${ }^{27}$ sino de un desarrollo mucho más largo que movilizó verdaderos rituales socioculturales. ${ }^{28} \mathrm{Si}$ el cristianismo se planteó entonces en España bajo el perfil social como aspecto fundamental de la unidad proto-nacional, al mismo tiempo comportaba conflictos jerárquicos no secundarios.

En cuanto al segundo factor propuesto, el desarrollo autónomo del ideal imperial en la España medieval, tenemos que, desde el siglo IX Alfonso III de Asturias adoptaría el título de emperador, algo que trescientos años después y al calor del avance de la Reconquista, revivirían Alfonso VI de Castilla y León ${ }^{29}$ y Alfonso VII de León como Imperator totius Hispaniae. ${ }^{30}$ Además, el primero, sin aceptar la intromisión papal en sus territorios, introdujo en sus reinos la liturgia romana. Y en cuanto al segundo, sus pretensiones quedaron plasmadas en el tomo dedicado a su historia, que lleva el elocuente título de Chronica Adefonsi imperatoris (1153-1157). En ésta, el autor anónimo asienta que imperium es el señorío sobre todas las tierras conquistadas $^{31}$. En esa misma época hubo escritores que llegaron a equiparar el prestigio y el poder del monarca con los de Carlomagno. ${ }^{32}$

Bajo el reinado de Alfonso X "el Sabio" el concepto evolucionaría; cabe hacer notar que en su corte residió el político y escritor italiano Brunetto Latini $^{33}$, — evocado en la Comedia de Dante- quien tuvo la oportunidad de desarrollar un influyente pensamiento político de corte aristotélico, relevante en las ulteriores teorías éticas y políticas escolásticas. ${ }^{34}$ Aunque el proyecto nunca se materializó, sí afloró por entonces la clara voluntad alfonsina de

26 Sánchez-Albornoz, España: un enigma histórico, vol. II, p. 9 y ss.

27 Valdeón Baruque, La reconquista. El concepto de España, p. 9.

28 O'Callaghan, Reconquest and Crusade, pp. 177-208.

29 O'Callaghan, "The Integration of Christian Spain into Europe”, pp. 102-104. Gambra, Alfonso VI: Cancillería, Curia e Impero, pp. 224-229.

30 Sería imposible desmenuzar en estas cortas páginas la complejidad del concepto de imperio desarrollado por los monarcas leoneses. El debate sobre su naturaleza es antiguo y para profundizar en él, véanse, entre otros: García Gallo, "El imperio medieval español”, pp. 199228; González Jiménez, "La idea de imperio antes y después de Alfonso VI", pp. 11-29; O'Callaghan, A History of Medieval Spain, pp. 193-214, 215-233, O'Callaghan, Reconquest and Crusade, p. 41, Reilly, The Kingdom of Leon-Castilla Under King Alfonso VII, 11261157, pp. 15-52, Webb Wheeler, "The Papacy and Hispanic Interstate Relations, 1195 1212 ", pp. 29-38.

31 Leonhard, "Introduction: The Longue Durée of Empire. Toward a Comparative Semantics of a Key Concept in Modern European History", pp. 1-5.

32 Muldoon, Empire and Order, p. 57.

33 Para una panorámica de las conexiones entre Alfonso X, Brunetto Latini y Dante Alighieri cfr. Martínez, "Alfonso X, Brunetto Latini y la historia de las primeras traducciones de la Ética aristotélica”, pp. 245-277 y Sowell, “Brunetto’s Tesoro in Dante’s Inferno, pp. 60-71.

34 Ferreiro Almparte, "Recepción de las éticas y de la política de Aristóteles en las Siete Partidas del Rey Sabio”, pp. 97-133. 
heredar el título y el oficio de Sacro Romano Emperador - conocido como "fecho del imperio"- e igualmente ello determinó también una modificación in fieri de los objetivos de las obras de derecho editadas en su época. Se abandonó así el proyecto original para publicar el Espejo de las leyes o Espéculo (1255-1260), que cedió paso a la que ha sido justamente llamada la "obra legal del imperio", ${ }^{35}$ es decir las Siete Partidas, concebidas a mediados del siglo XIII. Las Partidas representan el cambio de los intereses políticos-legislativos de Alfonso: son al mismo tiempo una profunda reflexión filosófica sobre la cuestión del derecho y un corpus de leyes dirigido a regular y unificar el derecho civil y canónico de los reinos de la península y reconfigurar el modelo de los ius proprium en un proyecto legislativo animado por un espíritu de aplicación pretendidamente universal. ${ }^{36} \mathrm{El}$ choque entre el esquema alfonsino y las tradicionales prerrogativas del cuerpo de la nobleza fue uno de los factores del fracaso del plan, pero es interesante hacer notar que en 1555 el texto de las Partidas sería publicado oficialmente por vez primera a instancias de la regente Juana de Austria y del presidente del Consejo de Indias, Gregorio López. ${ }^{37}$ Las mismísimas Partidas se encontraran de hecho en la base del discurso de legitimación de la Conquista, ${ }^{38}$ proporcionando elementos jurídicos basados en el antecedente histórico de la Reconquista ${ }^{39}$ y planteando ambas cruzadas "en términos de guerra defensiva y de recuperación de lo otrora usurpado por los musulmanes a los godos o a otros cristianos". ${ }^{40}$

Pérez-Martín, "La obra legislativa alfonsina y puesto que en ella ocupan las Siete Partidas", pp. 9-63.

36 Iglesias y Navarro, "Estrategias legislativas de Alfonso X en las Siete Partidas y la revuelta nobiliaria (1272-1273)", pp. 427-448.

37 Rodríguez-Velasco, "La urgente presencia de Las siete partidas", pp. 99-135.

38 Díez del Corral, La monarquía hispánica en el pensamiento político europeo: de Maquiavelo a Humboldt, Madrid, Revista de Occidente, 1975, Panateri, "Las imágenes del rey y del emperador en las Siete Partidas y la glosa de Gregorio López", Cuadernos de Historia del Derecho, núm. 22, 2015, pp. 215-255, Panateri, "El prólogo de Siete Partidas. Entropía, edición y uso político", Medievalia, núm. 47, 2015, <https://revistasfilologicas.unam.mx/medievalia/index.php/mv/article/view/307>, consultado el 23 de marzo de 2019, Panateri, "La ley en Las Siete Partidas", vol. 31, 2015, $<\mathrm{http} / /$ www.ehumanista.ucsb.edu/volumes/31>, consultado el 22 de marzo de 2019, Panateri, "Proyecto político y producción jurídica en Alfonso X. Consideraciones sobre la relación texto-contexto a partir de algunas variantes en sus proemios", Mirabilia: electronic journal of antiquity and middle ages, 2016, Issue 23, junio-diciembre, 2016, $<$ https://www.revistamirabilia.com/sites/default/files/pdfs/23.07.pdf $>$, consultado el 22 de marzo de 2019. Un último trabajo, interesante aunque no exento de críticas, es el de Villacañas Berlanga, ¿Qué imperio? Un ensayo polémico sobre Carlos Vy la España imperial.

39 Para una panorámica general y reciente, cfr. Bonch-Bruevich, "Ideologies of the Spanish Reconquest and Isidore's Political Thought", Mediterranean Studies, vol. 17, 2008, pp. 27-45.

40 Morín, “'La frontera de España es de natura caliente'. El derecho de conquista en las partidas de Alfonso X el Sabio", pp. 375-398. 
Es pues evidente que, desde época temprana en la historia medieval de la península ibérica, hay rastros ostensibles de procesos de legitimación imperial y de vinculación entre los asuntos temporales y espirituales a cargo de los soberanos.

\section{IV}

Estas ancestrales luchas de poder entre papado e imperio no desaparecerían durante la Edad Moderna, simplemente adoptarían nuevas formas. El proceso que formará el discurso sobre la monarquía universal en este período tal vez empezó a gestarse en la España del siglo XV cuando, a pesar de las profundas divisiones internas debidas a las diferentes ideas políticas de los monarcas de Castilla y Aragón, los avances de la fe católica impulsados por Isabel y Fernando los erigieron en nuevos campeones del cristianismo. La fe, utilizada como arma de asedio, fortaleció a los ejércitos cristianos cuya unificación fue causa de la capitulación del Reino nazarí de Granada, hecho que cierra finalmente el largo proceso de la Reconquista. ${ }^{41}$ La sucesiva expulsión de moros y judíos, la reformación del clero y de la Iglesia española, así como el proceso de desarrollo de una "sociedad inquisitorial" 42 fueron la impronta de un catolicismo combativo y marcaron el despuntar de una nueva super potencia europea.

La incisiva continuidad entre la acción militar de la Reconquista, que unificó territorialmente a España, y la acción ideológica del cristianismo, que la amalgamó ideológicamente, motivó a los papas Inocencio VIII (14841492) y Alejandro VI (1492-1503) a otorgar a Isabel y a Fernando el título de Reyes Católicos (sin que se soslaye su importante esfuerzo militar para liberar el reino pontificio de la ocupación del rey Carlos VIII de Francia). Estos vínculos entre las Coronas de España y el pontificado de Alejandro VI se extenderían también al asunto del Descubrimiento, coetáneo a la Reconquista, que impuso a los "cristianos verdaderos" la tarea de evangelizar a las Indias. Como veremos más adelante, el pontífice fue casi providencialmente llamado a conceder a los Reyes Católicos amplios derechos para la empresa de conversión de aquello que, en 1493, en la mentalidad europea, parecía todo, menos un imperio. Lo único que de todo esto me interesa destacar es la reconstrucción de la unidad española que involucra en una relación compleja a las monarquías de Castilla y Aragón con la institución pontificia.

41 Un resumen reciente en O'Callaghan, The Last Crusade in the West.

42 Suárez Fernández, Los Reyes Católicos: la expansión de la fe, pp. 33-74. 
Con esta cuestión volvemos de nuevo al tema de inicio del presente texto. El punto de pleamar del poderío español con Carlos de Habsburgo supuso simultáneamente una reconfiguración de la idea de imperio y una reorganización de las relaciones de éste con el pontificado. En cuanto a esto último, había un par de imperativos: la exigencia de una sanción sacralizadora de la autoridad imperial por parte de la Iglesia católica y, complementariamente, la necesidad de poner coto a las injerencias pontificias en el ejercicio del poder del emperador.

De ahí que el concepto de monarchia universalis volviera a ser objeto de un intenso debate justamente en el siglo XVI. Por un lado las acerbas críticas contra una monarquía supranacional de enorme poderío confirieron al concepto un aura bastante negativa. ${ }^{43}$ Por el otro, hubo una cauda de cronistas, historiadores, juristas e intelectuales cercanos al poder hispánico que tomaron los mismos hechos de la expansión imperial y de su creciente apartamiento de la intromisión pontificia para pintar un risueño panorama. Y éste no se limitaba a la esfera de las utopías políticas, sino que pretendía extenderse a la gestión práctica del poder y a las reformas necesarias.

Ciertamente, el programa reformista tomaba en cuenta concepciones políticas, jurídicas, religiosas y sociales, pero la pretensión genuina de la monarquía universal era cambiar el ethos de poblaciones enteras. Por ello, durante los reinados de Carlos I y luego el de su hijo, Felipe II, junto con el desarrollo de estrategias de expansión territorial y de propaganda retórica, se dieron palpables procesos de gestión social y de nuevas técnicas de diplomacia europea. Las teorías expresadas dos siglos atrás en Monarchia de Dante tuvieron revitalizada resonancia en esta época, cuando Europa cobró conciencia del alarmante crecimiento del poder de los Habsburgo. Sólo que ahora quienes echaron mano de ellas no las consideraron en el ámbito meramente teórico, sino que les dieron aplicación en el contexto político y administrativo.

A partir de 1519, Mercurino Arborio di Gattinara, gran canciller de Carlos I de España, desarrolla en sus escritos con vigoroso empuje la figura del Habsburgo como monarca universal a partir de las teorías de Dante. No se limita, empero, a subrayar el origen divino de su poder y, por tanto, su autoridad superior a la del pontífice, sino que destaca la importancia del alcance global de su potestad. ${ }^{44}$

Al respecto, hay especialistas que señalan que en la producción escrita de esta época el concepto de "imperio universal" se restringe al dominio euro-

43 Bosbach, "The European Debate in Universal Monarchy", p. 81.

44 Headley, "Germany, the Empire and Monarchia in the Thought and Policy of Gattinara", p. 18. 
peo, ${ }^{45}$ y que, en este sentido, la monarquía "universal" de Carlos sólo radicaría en la voluntad de igualar la expansión y el poder de la cristiandad latina y ortodoxa, ${ }^{46}$ es decir, en revivir la extensión imperial de los Romanos. Ciertamente, la imagen de los antiguos emperadores romanos fue bastante utilizada por los autores de aquel tiempo, como por ejemplo por Pedro Mexía en su Historia Ymperial y Cesárea; ${ }^{47}$ y sin embargo, hay otros estudiosos que plantean una teoría opuesta. Entre éstos prevalece la opinión de que la idea imperial de Carlos tenía un panorama bastante más extenso en cuanto al alcance de su poder. En este sentido, la historia del desarrollo de su lema plus ultra puede ser una pista bastante explicativa. ${ }^{48}$

La conexión con la tradición romana consistiría sobre todo en insertarse en un plano retórico que subrayaba la preminencia de la autoridad imperial sobre la papal, y que fue trazado por otros apologetas del Habsburgo. Alfonso de Valdés, humanista de escuela erasmiana y secretario imperial de la corte de Carlos V, suscribió una serie de textos apologéticos ${ }^{49}$ en los que hacía una encendida defensa de las prerrogativas imperiales. Otro defensor coetáneo ${ }^{50}$ de los privilegios imperiales, Jakob Köbel, sostenía que el imperio de Carlos era ya de facto una realidad jurídica y que el emperador no estaba sujeto al papa porque había recibido su autoridad sin intermediarios. ${ }^{51}$ En un tratado político, el Catholicum opus imperiale regiminis mundi, del navarro Miguel de Ulzurrun, ${ }^{52}$ se ocupaba de los problemas de la relación del imperio con la Iglesia y con los demás poderes políticos. Al afirmar el derecho de Carlos de gobernar a todos los pueblos a través de sus leyes imperiales, ${ }^{53}$ Ulzurrun limitaba finalmente la jurisdicción del pontífice y la confinaba al ámbito de las relaciones políticas entre los príncipes. ${ }^{54}$

Todos estos literatos deben sus propias ideas finalmente al canciller Gattinara - docto y elegante jurista - que se convirtió en el precursor de un verdadero topos propagandístico cuando decidió tomar el derecho y el modelo imperial romano para adaptarlos a la figura histórica de Carlos. Ya en el Monarchia de Dante, el Imperio romano era el sumo ejemplo de la civilización perfecta, al fundarse no en el ejercicio de la violencia sino de la ley. En

45 Bosbach, "The European Debate in Universal Monarchy", p. 90.

46 Johnson, "Some Peculiarities of Empire in the Early Modern Era", p. 494.

47 Mexia, Historia Ymperial y Cesárea.

48 Rosenthal, "The Invention of the Columnar Device of Emperor Charles V”, pp. 198-230.

49 Valdés, Diálogo de las cosas ocurridas en Roma e Valdés, Diálogo de Mercurio y Carón.

50 Johnson, "Some Peculiarities of Empire in the Early Modern Era", p. 496.

51 Köbel, Dialogus libertatis ecclesiastice defensorius.

52 Ulzurrun, Catholicum opus imperiale regiminis mundi.

53 Tubau, "Derecho, política y propaganda", p. 124.

54 Ibid., p. 125. 
la sucesiva adaptación de Gattinara hay sin embargo una evolución de la idea imperial respecto de la de Alighieri, que consideraba a la Península italiana como tierra imperial por excelencia. El gran canciller recuperó la noción de Ius italicum, que indica originariamente una serie de privilegios otorgados a ciudades y comunidades que, a través de una concesión imperial, ganaban de iure el estatus de ciudades italianas. Tal concepto, aplicado a todas las posesiones de los Habsburgo, marcaría la creación de uno de los ejemplos más claros de lo que se ha denominado monarquías compuestas. Éstas son formas de poder construidas a través del pactualismo entre la Corona y las clases dirigentes de las diferentes provincias, que constituyen una tácita y mutua aceptación capaz de conferir a la unión más arbitraria y artificial un sentido de estabilidad funcional en todo acto de gobierno. ${ }^{55}$

De ahí que la concepción monárquica de Carlos $\mathrm{V}$ se considere más amplia respecto de la del tradicional Imperio romano. La idea de autoridad imperial desarrollada por Gattinara se reveló una herramienta indispensable para gobernar la heterogeneidad de territorios, culturas y formas políticas heredada por los Habsburgo. El señorío de Carlos, según su gran canciller, tenía que manifestarse como una auctoritas supra-política, y no como un dominium directo como en la época romana. La idea imperial de Gattinara, finalmente, se caracteriza por su componente moral y legal. ${ }^{56}$ Esta nueva forma de entender la acción imperial dejaba bastante espacio de autogobierno a las entidades políticas menores incorporadas en los dominios de Carlos, reconocía suficiente autonomía a los poderes locales, y consentía que las élites tradicionales encontraran su propio sitio en la nueva red de relaciones de poder, ${ }^{57}$ aun si la aplicación del poder imperial en algunas áreas no siempre se daba de manera pacífica y se lograba únicamente a través de una mezcla de violencia y rituales sociales. ${ }^{58}$

Pero las ambiciones expansionistas del nuevo imperio no se limitaban únicamente a los aspectos geográfico y político. La veta confesional de la Corona española y sus vínculos con el catolicismo romano determinaron también el desarrollo de un "Estado misionero", ${ }^{59}$ en el que la otredad debía ser igualmente incorporada en un sentido cultural y religioso. ${ }^{60}$ Básicamente

La definición original de Koenisberger, composite states, fue retomada y ampliada por el historiador John Elliott que la rebautizó como composite monarchies. Cfr. Koenisberger, "Dominium Regale or Dominium Politicum et Regale", pp. 1-26. Elliott, "A Europe of Composite Monarchies", pp. 48-71.

57 Johnson, "Some Peculiarities of Empire in the Early Modern Era", p. 495.

58 Ruiz Ibáñez y Sabatini, "Monarchy as Conquest”, pp. 509-520.

59 De la Hera, Iglesia y Corona en la América Española, p. 32.

60 Johnson, "Some Peculiarities of Empire in the Early Modern Era", p. 495. 
por esta razón creo que en la época de Carlos V y Felipe II se desarrolla un complejo proceso de separación de instituciones.

Reteniendo el componente sacralizado del proceso de construcción del poder y de la imagen del emperador, bajo Felipe la monarquía española se deshace de la institución pontificia en lo que concierne a la administración de la Iglesia proto-nacional. En este sentido, y en un hecho bastante significativo, cabe mencionar la voluntad de la Corona de crear un Patriarcado de las Indias Occidentales (Patriarchatus Indiarum Occidentalium). Aun sin conocer el origen exacto de este oficio, ${ }^{61}$ puramente honorífico, sabemos que su creación se debe sobre todo a un interés particular del soberano de España, que reiterativamente pidió al pontífice su institución, semejante a los demás patriarcados que hay en la Iglesia. También en este asunto, la política regia y la pontificia tenían objetivos diferentes. El título fue finalmente instituido, pero en realidad el patriarca de las Indias Occidentales siempre ostentó un oficio que careció de facultades genuinas porque, además de la obligación de residir en Europa y no en las Indias bajo pena de ex comunión, le faltaban jurisdicción, clero y súbditos que regir. ${ }^{62}$ En cuanto a esto, nunca se olvidó el pontífice del Gran Cisma de Oriente de 1054, cuando bajo el influjo de los patriarcados la cristiandad oriental se separó irremediablemente de la occidental.

\section{V}

Como la temática que venimos analizando es la de la progresiva emancipación en el ámbito político de la autoridad civil respecto de la religiosa, me parece útil conectar a los aspectos retóricos otro factor importantísimo ya señalado: el rasgo confesional de la monarquía española. Esta cuestión la han atendido sobre todo los historiadores del derecho, ${ }^{63}$ pero en la historia del pensamiento ha sido casi pasada por alto.

La creciente autonomía de la Corona española respecto del papado y su paulatina pero creciente influencia en la estructura de una Iglesia hispánica que devino casi "nacional", puede enmarcarse en lo que John Headley define como un renacimiento del gibelinismo, ${ }^{64}$ que inicia bajo Carlos $\mathrm{V}$ pero que alcanza su cumplimiento con su heredero Felipe II.

61 Méndez Silva, Catálogo real y genealógico de España, p. 142.

62 Un trabajo que se ocupa de los posibles orígenes del oficio y de otros asuntos es el de Ruiz García, "Patriarcado de Indias y Vicariato General Castrense", pp. 449-471.

63 De la Hera, "La Monarchia Catholica española", p. 669.

64 Headley, "The Habsburg World Empire and the Revival of Ghibellinism”, pp. 45-79. 
En esta era de grandes mutaciones, el itinerario de la monarquía española se despliega en dos rutas. Como se ha dicho antes, Carlos V, Felipe II y sus consejeros intentan fundar la legitimidad del imperio y del monarca en la noción de un poder sacro, originariamente derivado del papado, y al mismo tiempo pretenden lograr la emancipación de la institución papal a pesar de conservar la vocación "católica" de su monarquía. ${ }^{65}$ Irónicamente, el germen de esta ruta se ubicó en la voluntad pontificia de ampliar su dominio espiritual a raíz de la aparición de las Indias Occidentales. Las generosas concesiones del papa Alejandro VI a los Reyes Católicos para la evangelización del Nuevo Mundo darían a éstos un enorme e inédito influjo en los asuntos eclesiásticos. Dichas facultades, ya propias de los reyes castellanos, crecerían a lo largo del siglo XVI y aún más allá, lo que determinaría de facto la exclusión pontificia de cualquier dinámica política de la Iglesia española.

Con todo, a mi parecer, esta gestión política de la autoridad eclesial de la que progresivamente se irían apropiando los soberanos de España es muy próxima o semejante a ciertos mecanismos desplegados por entonces en otras regiones europeas, por ejemplo, en Inglaterra y en Francia, donde las Iglesias proto-nacionales iniciaron una ruta de autonomización del papado desde el punto de vista teológico, merced a los influjos doctrinales de luteranos y calvinistas y a las respectivas reformas legales instrumentadas por la Reina Virgen y Le bon roi Henri.

Veamos el caso de Inglaterra. Desde el punto de vista teológico, la estructura de la Iglesia anglicana es formalmente calvinista. Esto obedece a un

Martínez Millán ha dedicado algunos trabajos a la interrelación/enfrentamiento entre los conceptos de imperio universal y monarquía católica. Entre otros: "Evolución de la Monarquía hispana: de la Monarchia Universalis a la "Monarquía católica" (siglos XVI-XVII)" y "La evaporación del concepto de "Monarquía católica': La instauración de los Borbones". Sin embargo, en este último (pp. 2145-2146) sostiene "que — desde el punto de vista del pensamiento político - el concepto de "Monarquía católica" se oponía a las ideas y prácticas políticas defendidas por Maquiavelo y — desde el punto de vista religioso — la "Monarquía católica" exigía la práctica de una religiosidad radical cuya ortodoxia era definida por Roma. De estos principios se deducía [...] que la identificación de la conducta política del monarca debía adecuarse a la ética católica”. Martínez Millán subraya, con razón, que la "aplicación de este sistema político-religioso tuvo grandes problemas a causa de la subordinación jurisdiccional que suponía la existencia de la Monarquía a los proyectos de Roma" (pp. 2146). Esto es precisamente el punto a discutir. Si en "la práctica de una religiosidad radical cuya ortodoxia era definida por Roma" insertamos únicamente los aspectos de la ética, de la dogmática y de la liturgia católicas romanas, podemos sin demasiados problemas concluir que los Austrias mayores permanecieron en el álveo de la ortodoxia. Habría que preguntarse, de todas formas, si el proyecto político-administrativo de Carlos V y Felipe II que caracterizó también a la estructura de la Iglesia española retuvo — en contrario de lo que plantea Martínez Millán - su característica "católica" exactamente en cuanto quería proponerse como principal motor de expansión del catolicismo y como hogar y reino para todos los cristianos del mundo. 
conocido proceso histórico: la mayoría del clero inglés de la era isabelina estaba constituida por ministros reformados que se habían refugiado en Ginebra durante el tiempo de la persecución de su antecesora, María Tudor, "la sanguinaria". A su regreso a la patria, simplemente ocuparon los puestos disponibles en las parroquias e iglesias. Por ello, los Treinta y nueve artículos de religión de la confesión anglicana suscritos por Isabel en 1571 no podían sino inspirarse de hecho en el calvinismo. ${ }^{66}$ Como lo plantea Gilberto Sacerdoti en su magistral estudio, en Inglaterra el asunto teológico de la Iglesia de Estado era algo secundario con respecto a la cuestión política: Isabel "buscaba tener en sus manos las riendas del gobierno eclesiástico". ${ }^{67}$ En el concepto de la Reina Virgen, la religión era un "acto de gobierno", una herramienta para suprimir el poder del papa en los asuntos temporales y para asumir la conducción de la administración eclesiástica. Así en el artículo XXXVII de la confesión de fe anglicana se establecía "la summa potestas de la autoridad regia tanto en los asuntos civiles como en los asuntos religiosos, excluyendo cualquier jurisdicción extranjera", ${ }^{68}$

Pero el caso de España fue distinto; históricamente mucho más impermeable a las transformaciones teológico-eclesiásticas del XVI, la península ibérica tuvo su recomposición interna en un marco absolutamente canalizado a través de la ortodoxia católica. Las reformas religiosas del arzobispo de Toledo Francisco Jiménez de Cisneros, operadas bajo el régimen de los Reyes Católicos, atendieron sobre todo a fortalecer la disciplina de los miembros de la Iglesia española y a infundir en la sociedad hispánica el pietismo popular. Estas reformas, por supuesto, dejaron intactos los núcleos doctrinales y dogmáticos del catolicismo romano; además, el poderoso instrumento de la recién fundada Inquisición española, bajo el control directo de la Corona, funcionó con eficiencia eliminando a las ramas más peligrosas de los reformadores. ${ }^{69}$ Ya en 1521 Adrián de Utrecht, inquisidor general de Aragón y Castilla y después papa bajo el nombre de Adriano VI (1522-

66 Patrick Collinson, John Craig and Brett Usher indican que la definición de "calvinista" para la Iglesia de Isabel es "demasiado tajante" [too blunt], porque de hecho el sistema anglicano en esa época "was a curious concoction, unique among the national churches of the reformation era". Cfr. Craig y Usher, Conferences and Combination Lectures in the Elizabethan Church, p. XXI. No obstante, será suficiente con analizar el título y el contenido, por ejemplo, de los artículos X, XI, XII, XIII, XVII y XXXI para notar el profundo influjo del calvinismo del siglo XVI. El léxico empleado en las reglas de la confesión de fe anglicana es técnicamente calvinista. Se habla de "blasfemia" en relación con el sacrificio de Cristo representado en la misa católica (art. XXXI), se niega el libre arbitrio (art. X), se declara que la salvación se realiza a través de la sola fide (art. XI).

67 Sacerdoti, Sacrificio e sovranità, pp. 16-17.

68 Ibid., p. 15.

69 Rawlings, The Spanish Inquisition, pp. 90-91. 
1523), prohibió y confiscó los textos luteranos que entraban a España a través de la ruta comercial de Flandes. Sin embargo, el problema real no radicaba tanto en la herejía protestante, pues las corrientes místicas-reformadas de España, de hecho, no fueron seducidas por las críticas doctrinales de Lutero o Calvino, ni rechazaron jamás el dogma católico. ${ }^{70}$ En cambio, para la unidad interna mucho más peligroso resultaba Erasmo de Rotterdam, cuya obra se convirtió en objetivo central de la censura. El filólogo neerlandés alcanzó gran éxito en España, pues no solo dio aliento a los trabajos de la Biblia políglota complutense, sino que también formó una generación entera de humanistas locales e incluso fue inspiración para grupos de heterodoxos españoles, tales como los alumbrados. De hecho, Gattinara en persona tuvo contacto con Erasmo para supervisar una nueva reedición del texto Monarchia de Dante Alighieri que apoyara su propia teoría imperial. ${ }^{71}$ Sin embargo, el erasmismo no fue bien visto por las autoridades peninsulares. ${ }^{72}$

Ciertamente, la legislación de Carlos V y de Felipe II en el plano estrictamente teológico no cuestionó la autoridad de la doctrina católica romana. ¿Pero qué hay del perfil político? Como ya se ha dicho, el proceso que llega a otorgar a los monarcas la soberanía sobre la vida y el desarrollo de la Iglesia, curiosamente, fue inaugurado por el pontífice mismo con los privilegios otorgados a los Reyes Católicos. Lo que inicialmente parecía una pequeña concesión, durante los reinados de Carlos $\mathrm{V}$ y de Felipe II evolucionó hasta convertirse en un "monstruoso" mecanismo de autogestión eclesiástica. $\mathrm{Si}$ por una parte hubo una censura casi total de la obra de Erasmo, si los reformadores alemanes y franceses no encontraron ecos en España para sus visiones teológicas heterodoxas, en contrario, las teorías políticas que se ligaban a todos ellos sí que alcanzaron éxito y difusión a través del instrumento del derecho.

Como punto de partida del proceso podemos considerar la teoría de la plenitudo potestatis del papado, que se seguía explicando a través de diferentes fórmulas ${ }^{73}$ y cuyo sentido había rebasado los confines originales que extendía desde el siglo XIII. Según ésta, el papa poseía una autoridad suprema en los asuntos temporales que no provenía de potentado terrenal alguno,

71 Yates, Astraea, p. 26. Headley, "The Habsburg World Empire and the Revival of Ghibellinism", p. 57.

72 Véase al respeto el clásico estudio de Bataillon, Erasmo y España, México, Fondo de Cultura Económica, 1956.

73 "Patet igitur ex dictis quibus communicata est potestas sacerdotalis, et quibus regia potestas, tam spiritualis quam secularis; et quod prelatis ecclesie utraque simul potestas conuenit, scilicet sacerdotalis uel pontificalis et regia spiritualis", Cfr. Giacomo da Viterbo, De regimine Christiano, p. 144. Otras fórmulas se encentran en Franciscus de Perusio Tractatus contra Bavarum, pp. 76-88 e Alvarus Pelagius, De Planctu ecclesiae. 
sino que era inherente al oficio papal mismo. Algunos teóricos del poder temporal papal subrayaron que éste era ejercitado por el pontífice en modo superiori et digniori et prestantiorii, ${ }^{74} \mathrm{y}$ sin embargo, es indudable que la institución pontificia interpretó tales prerrogativas no en un sentido patrimonial, sino en una acepción mucho más político-institucional. ${ }^{75}$ No obstante el ensanchamiento de los límites teóricos, es evidente que en la realpolitik el poder del papado encontraba un obstáculo difícil de eludir: carecía de las fuerzas necesarias para aplicar o imponer su poder temporal de facto en los territorios cristianos. Su supremacía en la esfera temporal tenía que expresarse apoyándose en otros príncipes que, pese a ser poseedores de un poder material mucho más fuerte, eran en todos los casos considerados inferiores al papa, tanto en dignidad temporal como espiritual. Esto es básicamente lo que por otro nombre se conoció como teocracia pontifical, teoría según la cual

es el romano pontífice, en unidad de poder y para mejor cumplir los fines de la redención, el que, por derecho divino, ha de gobernar el mundo entero. Señor de fieles e infieles, posee, por delegación de Cristo, una alta soberanía para señalar las rutas de la justicia, para intervenir en lo espiritual y en lo temporal, para nombrar y deponer reyes y príncipes, para trasladar imperios, cuando lo exija el bien de las almas y el fin espiritual de la Iglesia. ${ }^{76}$

Gracias sobre todo a las aportaciones de Enrico da Susa, el cardenal Ostiense, se extendía el dominio pontificio sobre los infieles y no únicamente sobre el orbe cristiano.

El papa que, según estos principios, ostentaba poder sobre las tierras de los infieles, podía entregarlas a los príncipes cristianos para que las cristianizasen; exactamente por esta razón Alejandro VI otorgó a los Reyes Católicos la soberanía sobre los territorios del Nuevo Mundo. El deber de evangelizar a los infieles resultaba altamente provechoso para ambas partes, pues, por un lado, el papado adquiría más almas para su rebaño y extendía su poder a los territorios recién descubiertos; por el otro, los soberanos de España podían justificar el asiento de su soberanía sobre las áreas allende el Atlántico.

Las concesiones pontificias de derechos legales a los reyes de España se remiten inicialmente a las conocidas Bulas Alejandrinas de 1493. A las dos

74 Giacomo da Viterbo, De regimine Christiano, p. 216.

75 A este respecto, por ejemplo, es interesante advertir cómo el papado, a través de los años, modifica la utilización de la Donación de Constantino. Cfr. Maffei, La donazione di Costantino nei giuristi medievali.

76 Castañeda Delgado, La teocracia pontifical en las controversias sobre el Nuevo Mundo, p. 15. 
Inter caetera, una de concesión ( 3 de mayo de 1493) y la otra de partición (4 de mayo de 1493), se añaden la Eximiae devotionis (3 de mayo de 1493) y la Dudum siquidem (26 de septiembre de 1493), que extiende los derechos precedentemente otorgados a los monarcas. A éstas se puede adjuntar un quinto documento, la bula Piis fidelium (25 de junio de 1493), que se dirige a fray Bernardo de Boil para encomendarle la primera misión de evangelización en el Nuevo Mundo.

Si bien estos documentos investían a los Reyes Católicos con amplísimas facultades para fines de la conversión, los gastos que suponía la evangelización de los infieles no eran un problema menor. De ahí la emisión de la bula Eximiae devotionis (16 de noviembre 1501), que ampliaba los derechos de los soberanos para cobrar y administrar el diezmo eclesiástico y que se dio con el ánimo de ayudarlos a subsanar el escollo del financiamiento. Empero, también resultó un factor de deslegitimación pontificia en los asuntos de política eclesiástica indiana.

Los avances de la fe experimentados en las Indias bajo el régimen de don Fernando el Católico estimularon al papa Julio II a ampliar ulteriormente los derechos ya conferidos. La bula Universalis Ecclesiae (28 de julio de 1508) estableció formalmente el Derecho de Patronato de España sobre las Indias y con él inauguró el proceso de autonomización del poder imperial sobre los asuntos eclesiásticos americanos. Hay que hacer notar que el documento pontificio no sólo aumentaba los derechos de los monarcas, sino que trocaba su condición transitoria y personal en un carácter perpetuo y, sobre todo, irrevocable por cualquier titular futuro de la misma institución que los otorgó. ${ }^{77}$

La transformación de España en un "Estado misionero"78 no es entonces tan sencilla como pudiera parecer a primera vista. La estructura retórica del imperio y la traba resultante de una concepción del poder de "tipo católico" seguían siendo importantes, pero únicamente a condición de liberarse de las injerencias papales en asuntos no estrictamente doctrinales. El desarrollo institucional no fue ni fácil ni rápido porque se fue fincando en concesiones previas; en último término la bula de 1508 y el correlativo Derecho de Patronato reproducían - aunque en mayor escala - un derecho precedente que consentía a los reyes de España presentar a la curia de Roma los candidatos al obispado de Granada. Éste fue el conocido derecho de presentación, otorgado para facilitar la conversión de los musulmanes que permanecieron en el

77 De la Hera, "El regio vicariato de Indias en las bulas de 1493”, p. 340, 342. De la Hera, "El regalismo indiano", p. 412.

78 Dougnac Rodríguez, Manual de historia del derecho indiano, p. 277. De la Hera, Iglesia y Corona en la América Española, p. 32. 
territorio después de la caída del último reino nazarí. Y aunque no inédito, el nuevo Derecho Patronal extendía esta prerrogativa de la presentación a cualquier cargo eclesiástico creado en las Indias, lo que determinó de facto el control real sobre la nueva Iglesia concebida ahora como herramienta regia.

La traslación de las prerrogativas políticas del ámbito eclesial del papa al monarca fue utilizada por éste en dos campos diferenciados: en la península sirvió para limitar o erradicar la injerencia pontificia en los asuntos eclesiásticos internos; en las Indias - donde la influencia papal fue siempre menor que en Europa - ${ }^{79}$ se aplicó para contener a las poderosas órdenes mendicantes.

El mayor despliegue a este respecto se dio en América, con la Real Cédula de Patronazgo de Felipe II, fechada en 1574, que es tal vez el documento que nos transmite con más claridad y fuerza este proceso ${ }^{80}$ y que, en las amargas palabras de la Historia del padre Mariano Cuevas, ${ }^{81}$ nos permite también entender el alcance del poder del monarca de Castilla. Sin embargo, ésta es únicamente la culminación de un proceso que empezó a desarrollarse un poco antes, en 1567, cuando Juan de Ovando fue nombrado visitador del Consejo de Indias. Sus indagaciones fueron la base de la convocatoria a la Junta Magna del año siguiente, 1568, que pretendía resolver los asuntos más problemáticos de la gestión virreinal y, entre ellos, los que afligían la institución eclesiástica en las Indias Occidentales. Esa fue una buena ocasión para discutir nuevamente la estructura entera de la Iglesia indiana, a la luz de las quejas y el malestar de los frailes misioneros que amenazaban con saltarse la autoridad regia para pedir directamente al papa las estrategias de evangelización. ${ }^{82}$ Pero sobre todo, esta Junta fue una respuesta contundente a la corriente de pensamiento que por entonces se gestaba alrededor del trono de Pedro: la iniciativa de los consejeros políticos de Pío V de establecer una institución para organizar minuciosamente la evangelización de los infieles americanos, proyecto que, de concretarse, finalmente "anularía la función confiada a los reyes de España por Alejandro VI, máxime cuando el papa

79 Destacamos que, por ejemplo, el único y último vicario pontificio en las Indias fue, justamente, Bernardo Boil. Cfr. De la Hera, Iglesia y Corona en la América Española, pp. 97-99.

80 García Añoveros, La Monarquía y la Iglesia en América, pp. 105-106.

81 "Lo más desagradable tal vez del patronato es el empeño en aislarnos de Roma" Cfr. Cuevas, Historia de la Iglesia en México, vol. II, p. 52.

82 En este respecto hay un caso bastante conocido en el franciscano fray Alonso Maldonado de Buendía. Cfr. Borges, "Un reformador de Indias y de la Orden Franciscana", pp. 281-337, 487-535. Assadourian, "Fray Alonso de Maldonado", pp. 623-661. Por la injerencia papal operada a través de los misioneros cfr. también la Carta de los Comisarios de 1562 en Zabálburu y Rayon, Nueva colección de documentos inéditos, vol. 6, p. 47. 
también acariciaba la idea de que un nuncio debería instalarse en las Indias, para entender en todos los problemas eclesiásticos". 83

Si el aprovechamiento de los derechos patronales era un punto muy importante de la acción de Felipe II en las Indias y en España, lo difuso de sus límites y alcances permitieron a los monarcas ajustar el contenido de tal cesión de poder, motu proprio por parte del papado, a los vaivenes y las necesidades de la política imperial. Podemos decir que la Corona española organizó su soberanía política sobre la Iglesia "nacional" en tres diferentes órdenes. ${ }^{84} \mathrm{El}$ primero se basó en concesiones papales efectivas, que entregaron a la Corona las facultades de proponer sus candidatos a todos los oficios eclesiásticos indianos — desde el cura del más remoto y humilde pueblo hasta el mismísimo arzobispo de una diócesis metropolitana- y de cobrar y administrar el diezmo eclesiástico. En esta categoría y a estos dos derechos básicos se pueden añadir la prerrogativa de fijar los límites de los obispados y la de controlar y gestionar los conflictos administrativos entre órdenes religiosas y obispos.

El segundo se estructura sobre el primero y va por iniciativa y cuenta de la propia Corona de España, que se auto-concede el derecho de operar en el fuero eclesiástico a través de los tribunales civiles, el de limitar las visitas episcopales reglamentarias a la Santa Sede (visitas ad limina), el de controlar el flujo de informaciones entre la institución pontificia y los obispos españoles (peninsulares y novohispanos), el de obligar a los cabildos eclesiásticos en sede vacante a nombrar un vicario capitular elegido por la autoridad civil y, finalmente, el de manejar en primera instancia una facultad que, desde la época medieval, fue patrimonio de la Iglesia: la de juzgar a los miembros del clero.

El tercero, a veces tildado de "ejercicio abusivo del Patronato", llega a constituir la "herejía administrativa" 85 propia de las monarquías regalistas de España. Aquí encontramos las disposiciones que decretan la aplicación automática del Regium exequatur (o pase regio) sobre las decisiones papales canalizado a través del Consejo de Indias. Por virtud de este privilegio, que se arrogaron los reyes de España, cualquier documento expedido por el papado era sometido a examen previo por parte del rey y de los órganos de gobierno, quienes decidían discrecionalmente sobre su aplicación, al menos en las Indias. También hay que incluir aquí la prohibición de la divulgación

85 De la Hera, "Evolución de las doctrinas sobre las relaciones entre la Iglesia y el Estado", p. 273. 
y lectura de la bula anual In Coena Domini ${ }^{86}$ que a partir de 1568 el papado sacaba cada Jueves Santo. En ella se consignaban cinco nuevos artículos explícitamente dirigidos a censurar el cesaropapismo. Se cuenta igualmente en este rubro la legitimación del "Recurso de fuerza", es decir, la posibilidad de que los magistrados civiles rechazaran o rectificaran las sentencias de los tribunales eclesiásticos, lo que era sin duda una prolongación excesiva del poder de los órganos judiciales seculares sobre la gestión de los concilios provinciales o de los sínodos diocesanos. El destino de los decretos del Concilio de Trento en las provincias americanas, aplicados a la Iglesia de la Nueva España a través del Tercer Concilio Provincial Mexicano ${ }^{87}$ de 1585, me parece otro claro indicador de que el control regio de la política eclesiástica fue mucho más allá de una simple "herejía administrativa".

\section{ConClusiones}

Que España permaneció doctrinalmente y tout court dentro de los límites del dogma católico es una paradoja, pues simultáneamente se trata de algo evidente, pero, en el fondo, no tan obvio.

El repaso que se ha hecho aquí, somero y vuelapluma, sobre la génesis de las disputas entre dos entidades, imperio y papado, a partir de la crisis ulterior a la caída del Imperio romano de Occidente, no pretendía agotar el análisis de un tema complejo y de múltiples artistas, sino sólo aportar un panorama general para fijar en la Monarchia de Dante Alighieri, escrita a principios del siglo XIV, un punto de innovación en la tratadística filosóficojurídica sobre las relaciones jerárquicas entre poder temporal y poder espiritual. A mi juicio, esta obra representa el fundamento para la posterior reflexión que sobre el género hiciera el gran canciller Mercurino Arborio di Gattinara. Sin embargo, y a diferencia de Dante, la actividad política de Gattinara se desarrolló en un contexto europeo donde el poderío de la Casa de Austria se expandió en escala nunca antes vista: no sólo sobre linderos geográficos, sino también sobre los confines ideales de la autoridad y la

86 El documento se dirige tradicionalmente, desde la época de Honorio III (1216-1227), a la excomunión impuesta por crímenes específicos contra la fe y la moral católicas y fue siempre el objeto de duras críticas por la exagerada reivindicación del poder por parte de la autoridad pontificia. Cfr. Cross y Livingstone, The Oxford Dictionary of the Christian Church, p. 824. Las transformaciones de la bula In Coena Domini y de su empleo como recurso político han sido analizadas en el trabajo de Bravo Lira, "El problema de la Bula de la Cena en tres juristas indianos del siglo XVII”, pp. 187-194.

87 Martínez Ferrer, "Los decretos del Tercer Concilio Provincial Mexicano (1585)", pp. 27-56. Véanse también los estudios introductorios de Martínez Ferrer, Decretos del concilio tercero provincial mexicano. 
potestad, para alcanzar metas que, apenas unos años antes, hubieran sido impensables.

La concentración de poder en las manos de Carlos $\mathrm{V}$ comportó forzosamente una multitud de problemas derivados de la heterogeneidad de sus dominios; por ello Gattinara, basándose en las ideas de Dante, desarrolló una teoría política que, al tiempo que confederara la diversidad en una unidad, autonomizara el poder civil-temporal de las injerencias papales.

A pesar de que el magno y audaz proyecto político del gran canciller hubiera fracasado a la postre, luego de la abdicación de Carlos V y de la partición de sus dominios entre su hijo Felipe y su hermano Fernando, no se perdió la conexión entre la idea de la monarquía católica y el imperio universal, que perceptiblemente siguió su curso en las acciones políticas de Felipe II. En este sentido, la aparición de las Indias Occidentales en el juego de ajedrez mundial y la brillante explotación de los beneficios de las Bulas Alejandrinas por parte del Rey Prudente contribuyeron al progresivo e inexorable cisma entre el poder civil-temporal y el espiritual. De ahí que me hubiera parecido oportuno comparar, si bien con todas las precauciones del caso, las transformaciones del sistema monárquico español de Felipe II con la evolución de las relaciones de poder civil-temporal en otros territorios que, a diferencia de España, fueron atropelladas por las reformas protestantes. Puesto que, si desde la perspectiva de la ortodoxia ética y litúrgica, España permaneció en el corazón de la "romanidad", desde el punto de vista de la política, es más que lícito avanzar algunas dudas.

En mi opinión, los derechos de Patronato, que luego desarrollarían sin mesura los juristas españoles hasta culminar con la invención del llamado "vicariato regio" durante el siglo XVII, ${ }^{88}$ tienen por antecedente y remiten inevitablemente a la retórica de la supremacía imperial que el gibelinismo de Gattinara volvería a afinar a principios del XVI. De hecho, el canciller era exponente de un catolicismo muy poco conectado con la concepción romana $^{89}$ y un firme partidario de la política conciliar de la Iglesia, parte integral de una corriente de pensamiento que veía al papa sobre todo en términos políticos, como el señor de los Estados Pontificios. ${ }^{90}$ Por ello, Mercurino Gattinara se propuso reducir el poder papal básicamente a una función pastoral. Fue lo bastante sagaz para oponerse, por un lado, a cualquier iniciativa pontificia de intervención en asuntos seculares y, por el otro, para promover

89 Como se puede apreciar en la documentación recopilada por Carlo Bornate, Ricerche intorno alla vita di Mercurino Gattinara, pp. 263-266.

90 Headley, "The Habsburg World Empire and the Revival of Ghibellinism", pp. 53-59. 
las exigencias del emperador de inmiscuirse en el ámbito espiritual. ${ }^{91}$ Dicho proyecto trascendió a Gattinara y a Carlos V y se consolidó bajo Felipe II, a grado tal que no alcanza a percibirse gran diferencia entre la concepción de la Iglesia que se plasma en la Real Cédula de Patronazgo y la que expresa el artículo XXXVII de la Iglesia Anglicana:

Su majestad $[\ldots]$ tiene el poder supremo en este reino $[\ldots]$ y en otros dominios suyos, a los cuales el gobierno supremo de todos los Estados de este reino, sean eclesiásticos o civiles y en todas las causas pertenece, y no es ni debería estar sujeto a ninguna jurisdicción extranjera". ${ }^{92}$

\section{BibLIOGRAFíA}

Alighieri, Dante, Opere minori di Dante Alighieri. Il convivio. Epistole. Monarchia e Questio de aqua et terra, Torino, UTET, 1997.

Alvarus Pelagius, De Planctu ecclesiae, Lugdunum, Cleyn, 1517.

Angelov, Dimiter, Imperial Ideology and Political Thought in Byzantium, 12041330, New York, Cambridge University Press, 2007.

Assadourian, Carlos Sempat, "Fray Alonso de Maldonado: la política indiana, el estado de damnación del Rey Católico y la Inquisición”, Historia Mexicana, vol. 38, núm. 4, 1989, pp. 623-661.

Bataillon, Marcel, Erasmo y España, México, Fondo de Cultura Económica, 1956.

Black, Jeremy, European Warfare, 1494-1660. Warfare and History, London, Routledge, 2002.

Bonch-Bruevich, Xenia, "Ideologies of the Spanish Reconquest and Isidore's Political Thought", Mediterranean Studies, no. 17, 2008, pp. 27-45.

Borges, Pedro, "Un reformador de Indias y de la Orden Franciscana bajo Felipe II: Alonso Maldonado de Buendía, O.F.M", Archivo Ibero-Americano, núm. 20, 1960, pp. 281-337, 487-535.

Bornate, Carlo, Ricerche intorno alla vita di Mercurino Gattinara, Gran Cancelliere di Carlo V, Novara, Miglio, 1899.

Bosbach, Franz, "The European Debate in Universal Monarchy", Armitage, D., Theories of Empire 1400-1800, London, Routledge, 1998, pp. 81-98.

$91 \quad$ Ibid., p. 55.

92 Traducción mía; la cita textual completa indica: “The Queen's Majesty hath the chief power in this realm of England and other her dominions, unto whom the chief government of all estates of this realm, whether they be ecclesiastical or civil, in all causes doth appertain, and is not nor ought to be subject to any foreign jurisdiction". 
Bravo Lira, Bernardino, "El problema de la Bula de la Cena en tres juristas indianos del siglo XVII" en VII Congreso del Instituto Internacional de Historia del Derecho Indiano, vol. I, Buenos Aires, 1984, pp. 187-194.

Cañeque, Alejandro, "Imaging the Spanish Empire: The Visual Construction of Imperial Authority in Habsburg New Spain”, Colonial Latin American Review, vol. 19, no. 1, 2010, pp. 29-68.

Castañeda Delgado, Paulino, La teocracia pontifical en las controversias sobre el Nuevo Mundo, México, UNAM, Instituto de Investigaciones Jurídicas, 1996.

Cassell, Anthony K., The Monarchia Controversy. An Historical Study with Accompanying Translations of Dante Alighieri's Monarchia, Guido Vernani's Refutation of the "Monarchia" Composed by Dante, and Pope John XXII's Bull Si fratrum, Washington D.C., The Catholic University of America Press, 2004.

Cengarle, Federica, "Potestas condendi leges: The Erosion of a Civic Prerogative under the Pressure of Princely Rule", Daniel Bornstein, Laura Gaffuri, y Brian Jeffrey Maxson, Languages of Power in Italy (1300-1600), Turnhout, Brepolis, 2017, pp. 113-128.

Collins, Roger, “¿Dónde estaban los arrianos en el año 589?”, Gonzálvez Ruiz, R., El Concilio III de Toledo. XIV Centenario, Toledo, 1991, pp. 211-222.

, Visigothic Spain: 409-711, Oxford, Blackwell, 2004.

Collinson, Patrick, John Craig y Brett Usher, Conferences and Combination Lectures in the Elizabethan Church: Dedham and Bury St Edmunds, 1582-1590, Woodbridge, The Boydell Press, 2003.

Cross, Frank F. y Elizabeth A. Livingstone, The Oxford Dictionary of the Christian Church, Oxford, Oxford University Press, 2005.

Cuevas, Mariano, Historia de la Iglesia en México, México, Imprenta del Asilo "Patricio Sanz", 1922.

De la Hera, Alberto, "El regio vicariato de Indias en las bulas de 1493", Anuario de historia del derecho español, núm. 29, 1956, pp. 317-350.

, "Evolución de las doctrinas sobre las relaciones entre la Iglesia y el Estado", en varios autores, Derecho Canónico, vol. 2, Pamplona, Eunsa, 1974, pp. 241-282.

, "El regalismo indiano", Ius Canonicum, vol. 32, núm. 64, 1992, pp. 411437.

, Iglesia y Corona en la América Española, Madrid, Mapfre, 1992.

, "La Monarchia Catholica española", Anuario de historia del derecho español, núm. 67, 1997, pp. 661-676.

Decretum magistri Gratiani ed. Lipsiensis secunda post Aemilii Ludovici Richteri curas ad librorum manu scriptorum et editionis Romanae fidem recognovit et adnotatione critica instruxit Aemilius Friedberg, Leipzig, 1879. $<$ http://geschichte.digitale-sammlungen.de/decretum-gratiani/online/angebot $>$, consultado el 25 de septiembre de 2016. 
Díez del Corral, Luis, La monarquía hispánica en el pensamiento político europeo: de Maquiavelo a Humboldt, Madrid, Revista de Occidente, 1975.

Digesta Iustiniani Augusti ed. Mommsen, T. y Krueger, P. Berlin, Weidmann, 1870. $<$ http://droitromain.upmf-grenoble.fr/Corpus/digest.htm>, consultado el 25 septiembre de 2016.

Dougnac Rodríguez, Antonio, Manual de historia del derecho indiano, México, UNAM, Instituto de Investigaciones Jurídicas, 1994.

Elliott, John, “A Europe of Composite Monarchies", Past and Present, vol. 137, núm. 1, 1992, pp. 48-71.

Fernández Conde, Francisco Javier, "Bretones o británicos en Asturias durante los primeros siglos medievales", Gómez Tabanera, J. M., En torno al bimilenario del Eo, Oviedo, Foro Cultural del Noroeste, San Tirso de Abres, 2002, pp. 463-472.

Ferreiro Almparte, Jaime, "Recepción de las éticas y de la política de Aristóteles en las Siete Partidas del Rey Sabio", Glossae: European Journal of Legal History, núm. 1, 1988, pp. 97-133.

Firpo, Massimo, Il Sacco di Roma del 1527. Tra profezia, propaganda politica e riforma religiosa, Cagliari, CUEC, 1990.

Firpo, Massimo, "Il sacco di Roma e la sua eredità", en Riforma protestante ed eresie nell'Italia del Cinquecento, Bari 1997, pp. 106-109.

Franciscus de Perusio (Francesco Toti), "Tractatus contra Bavarum”, Scholz, R., Unbekannte Kirchenpolitische Streitschriften aus der Zeit Ludwigs des Bayern (1327-1354), Roma, Verlag Von Loescher \& C, 1910 [1328], vol. II, pp. 76-88.

Frankl, Viktor, "Imperio particular e Imperio Universal en las Cartas de Relación de Hernán Cortés", Armitage, D., Theories of Empire 1400-1800, London, Routledge, 1998, pp. 99-138.

Gambra, Andrés, Alfonso VI: Cancillería, Curia e Imperio, León, Centro de Estudios e Investigación "San Isidoro", 1998.

García Añoveros, Jesús María, La Monarquía y la Iglesia en América, Madrid, Asociación Francisco López de Gómara, 1990.

García Gallo, Alfonso, "El imperio medieval español”, Arbor, núm. 4, 1945, pp. 199228.

García Villada, Zacarías, Historia Eclesiástica de España, Madrid, Compañía IberoAmericana de Publicaciones, 1929.

Giacomo da Viterbo, De regimine Christiano, edición crítica por Dyson R. W., Leiden-Boston, Brill, 2006.

González Jiménez, Manuel, "La idea de imperio antes y después de Alfonso VI", Fernando Suárez y Andrés Gambra, Alfonso VI, Imperator totius orbis Hispaniae, Madrid, Sanz y Torres, 2010. 
Headley, John M., "Germany, the Empire and Monarchia in the Thought and Policy of Gattinara", Lutz, H., Das römisch-deutsche Reich im politischen System Karls V, Munich, Oldenbug, 1982, pp. 15-34.

, "The Habsburg World Empire and the Revival of Ghibellinism", Armitage, D., Theories of Empire, 1450-1800, London, Routledge, 1998, pp. 45-79.

Hillerbrand, Hans J., "Martin Luther and the Bull Exsurge Domine", Theological Studies, no. 30, 1969, pp. 108-112.

Iglesias, Yolanda y Navarro, David, "Estrategias legislativas de Alfonso X en las Siete Partidas y la revuelta nobiliaria (1272-1273)", Studia Iberica et Americana: journal of Iberian and Latin American literary and cultural studies, vol. 1, no. 3, 2016, pp. 427-448.

Johnson, Carina L., "Some Peculiarities of Empire in the Early Modern Era", Ocker, C., Printy, M., Starenko, P., y Wallace, P., Politics and Reformations: Communities, Polities, Nations, and Empires, Leiden-Boston, Brill, 2007, pp. 491-512.

Kamen, Henry, Spain 1469-1714. A Society in Conflict, Edinburgh Gate, Pearson Longman, 2005.

Keen, Maurice H., The Laws of War in the Late Middle Ages, London, Routledge, 1965.

Knecht, Robert J., Renaissance Warrior and Patron: The Reign of Francis I, New York, Cambridge University Press, 1994.

Koenisberger, Helmut G., "Dominium Regale or Dominium Politicum et Regale", Koenisberger, Helmut G., Politicians and Virtuosi: Essays on Early Modern History, London, A\&C Black, 1986, pp. 1-26.

Köbel, Jakob, Dialogus libertatis ecclesiastice defensorius cum Imperatorum sanctionibus, Oppenheim, 1516. < http://reader.digitale-sammlungen.de/resolve/ display/bsb11227091.html>, consultado el 25 de septiembre de 2016.

Leonhard, Jörn, "Introduction: The Longue Durée of Empire. Toward a Comparative Semantics of a Key Concept in Modern European History", Contributions to the History of Concepts, vol. 8, no. 1, 2013, pp. 1-25.

Lesaffer, Randall, Peace Treaties and International Law in European History: From the Late Middle Ages to World War One, Cambridge, Cambridge University Press, 2004.

Logan, Francis D., A History of the Church in the Middle Ages, London-New York, Routledge, 2002.

Maffei, Domenico, La donazione di Costantino nei giuristi medievali, Milano, Giuffrè, 1964.

Mallett, Michael E., y Christine Shaw, The Italian Wars, 1494-1559: War, State and Society in Early Modern Europe, Harlow, Pearson Education Limited, 2012.

Martínez, H. Salvador, "Alfonso X, Brunetto Latini y la historia de las primeras traducciones de la Ética aristotélica”, Estudios Humanísticos. Filología, núm. 39, 2017, pp. 245-277. 
Martínez Diez, Gonzalo y Félix Rodríguez Barbero, La colección canónica hispana,

IV. Concilios Galos. Concilios Hispanos: Primera Parte, Madrid, CSIC, 1984.

Martínez Diez, Gonzalo, y Félix Rodríguez Barbero, La colección canónica hispana,

V. Concilios Hispanos: Segunda parte, Madrid, CSIC, 1992.

— L La colección canónica hispana, VI. Concilios Hispánicos: Tercera parte, Madrid, CSIC, 2002.

Martínez Ferrer, Luis, Decretos del concilio tercero provincial mexicano (1585), México, El Colegio de Michoacán-Universidad Pontificia de la Santa Cruz, 2010.

, "Los decretos del Tercer Concilio Provincial Mexicano (1585). Problemas y posibilidades de su edición crítica", Lira González, A., Carrillo Cázeres, A. y Ferreira Ascencio, C., Derecho, política y sociedad en Nueva España a la luz del Tercer Concilio Provincial Mexicano (1585), Zamora, El Colegio de Michoacán, El Colegio de México, 2013, pp. 27-56.

Martínez Millán, José, 'La evaporación del concepto de 'Monarquía católica' La instauración de los Borbones”, José Martínez Millán, Concepción Camarero Bullón, Marcelo Luzzi Traficante, La Corte de los Borbones: Crisis del modelo cortesano, vol. 3, Polifemo, 2013, pp. 2143-2196.

, "Evolución de la Monarquía hispana: de la Monarchia Universalis a la "Monarquía católica" (siglos XVI-XVII)", Leonardo Funes, Hispanismos del mundo: diálogos y debates en (y desde) el sur, Buenos Aires, Miño y Dávila Editores, 2016, pp. 107-130.

Martínez Pizarro, Joaquín, The Story of Wamba: Julian of Toledo's Historia Wambae Regis, Washington D.C., The Catholic University of America Press, 2012.

Méndez Silva, Rodrigo, Catálogo real y genealógico de España ascendencias y descendencias de nuestros Católicos Príncipes y Monarcas Supremos, Madrid, Imprenta de Doña Mariana del Valle, 1656.

Mexia, Pedro, Historia Ymperial y Cesárea, Sevilla, Sebastián Trujillo, 1545.

Morín, Alejandro, “'La frontera de España es de natura caliente'. El derecho de conquista en las partidas de Alfonso X el Sabio", Martín Ríos Saloma, El mundo de los conquistadores, México, Universidad Nacional Autónoma de México, Instituto de Investigaciones Historicas, Silex Ediciones, pp. 375398.

Morris, Colin, The Papal Monarchy. The Western Church from 1050 to 1250, Oxford, Clarendon Press, 1989.

Muldoon, James, Empire and Order. The Concept of Empire, 800-1800, London, Palgrave Macmillan UK, 1999.

Nederman, Cary J., "From Defensor pacis to Defensor minor: the problem of empire in Marsiglio of Padua", History of Political Thought, vol. 16, núm. 3, marzo 1995, pp. 313-329. 
- Lineages of European Political Thought: Explorations Along the Medieval/Modern Divide from John of Salisbury to Hegel, Washington D.C., The Catholic University of America Press, 2009.

Nicol, Donald M., The Last Centuries of Byzantium, 1261-1453, New York, Cambridge University Press, 1993.

O'Callaghan, Joseph F., A History of Medieval Spain, Ithaca and London, Cornell University Press, 1975.

, "The Integration of Christian Spain into Europe: The Role of Alfonso VI of Leon-Castile", Reilly, B. F., Santiago, Saint-Denis, and Saint Peter: The Reception of the Roman Liturgy in Leon-Castile in 1080, New York, Fordham University Press, 1985, pp. 101-120.

- Reconquest and Crusade in Medieval Spain, Philadelphia, University of Pennsylvania Press, 2003.

- The Last Crusade in the West. Castile and the Conquest of Granada, Philadelphia, University of Pennsylvania Press, 2014.

Panateri, Daniel, "La ley en Las Siete Partidas", eHumanista: Journal of Iberian Studies, núm. 31, 2015, <http://www.ehumanista.ucsb.edu/volumes/31>, consultado el 22 de marzo de 2019.

, "Las imágenes del rey y del emperador en las Siete Partidas y la glosa de Gregorio López", Cuadernos de Historia del Derecho, núm. 22, 2015, pp. 215-255.

, "El prólogo de Siete Partidas. Entropía, edición y uso político", Medievalia, núm. $\quad 47, \quad 2015, \quad<$ https://revistas-filologicas.unam.mx/medievalia /index.php/mv/article/view/307>, consultado el 23 de marzo de 2019.

"Las Siete Partidas como escenario de conflicto político", Revista Chilena de Estudios Medievales, núm. 9, enero-junio 2016, pp. 79-102.

Panateri, "Proyecto político y producción jurídica en Alfonso X. Consideraciones sobre la relación texto-contexto a partir de algunas variantes en sus proemios", Mirabilia: electronic journal of antiquity and middle ages, núm. 23, junio-diciembre, 2016,

https://www.revistamirabilia.com/sites/default/files/pdfs/23.07.pdf>, consultado el 22 de marzo de 2019.

Passerin d'Entrèves, Alessandro, Dante as a Political Thinker, Oxford, Clarendon Press, 1965.

Pérez-Martín, Antonio, "La obra legislativa alfonsina y puesto que en ella ocupan las Siete Partidas", Glossae. Revista de historia del derecho europeo, núm. 3, 1992, pp. 9-63.

Ramos, Demetrio, "La crisis indiana y la Junta Magna de 1568" en Jahrbuch für Geschichte Lateinamerikas-Anuario de Historia de América Latina, vol. 23, núm. 1, 1986, pp. 1-61.

Riley, Bernard F., The Kingdom of Leon-Castilla Under King Alfonso VII, 11261157, Philadelphia, University of Pennsylvania Press, 1998. 
Rodríguez-Velasco, Jesús D., "La urgente presencia de Las siete partidas”, La corónica: A Journal of Medieval Hispanic Languages, Literatures, and Cultures, vol. 38, núm. 2, 2010, pp. 99-135.

Rosenthal, Earl E., "The Invention of the Columnar Device of Emperor Charles V at the Court of Burgundy in Flanders in 1516", Journal of the Warburg and Courtauld Institutes, núm. 36, 1973, pp. 198-230.

Ruiz García, Felix, "Patriarcado de Indias y Vicariato General Castrense", Revista Española de Derecho Canónico, vol. 23, núm. 65, 1967, pp. 449-471.

Ruiz Ibáñez, José J. y Gaetano Sabatini, “Monarchy as Conquest: Violence, Social Opportunity, and Political Stability in the Establishment of the Hispanic Monarchy", The Journal of Modern History, vol. 81, núm. 3, 2009, pp. 501 536.

Rawlings, Helen, The Spanish Inquisition, Malden, Blackwell, 2006.

Russell, Frederick H., The Just War in the Middle Ages, Cambridge, Cambridge University Press, 1975.

Sacerdoti, Gilberto, Sacrificio e sovranità. Teologia e politica nell'Europa di Shakespeare e Bruno, Torino, Einaudi, 2002.

Sánchez-Albornoz, Claudio, España: un enigma histórico, Buenos Aires, Editorial Sudamericana, 1956.

Sandoval, Prudencio de, Historia de la vida y hechos del emperador Carlos V, máximo, fortísimo, Rey Católico de España y de las Indias, islas, y tierra firme del mar océano, Madrid, Ediciones Atlas, 1955.

Sigmund, "The Influence of Marsilius of Padua on XVth-Century Conciliarism", Journal of the History of Ideas, vol. 23, núm. 3, julio-septiembre 1962, pp. 392-402.

Sowell, Madison U., “Brunetto's Tesoro in Dante's Inferno”, Lectura Dantis, núm. 7, 1990, pp. 60-71.

Suárez Fernández, Luis, Los Reyes Católicos: la expansión de la fe, Madrid, Rialp, 1990.

Tanner, Marie, The Last Descendant of Aeneas. The Hapsburgs and the Mythic Image of the Emperor, New Haven, Yale University Press, 1993.

Tubau, Xavier, "Derecho, política y propaganda: los juristas y el imperio de Carlos V", en Fosalba Vela, E., y Pontòn, G., La escondida senda: estudios en homenaje a Alberto Blecua, Barcelona-Buenos Aires, Castalia Ediciones, 2012, pp. 121-145.

Ulzurrun, Miguel de, Catholicum opus imperiale regiminis mundi, Zaragoza, Jorge Cocci, 1525, <http://fondosdigitales.us.es/fondos/libros/2085/2/catholicumopus-imperiale-regiminis-mundi>, consultado el 25 de septiembre de 2016.

Valdeón Baruque, Julio, La reconquista. El concepto de España: unidad y diversidad, Madrid, Espasa-Calpe, 2006.

Valdés, Alfonso de, Diálogo de las cosas ocurridas en Roma, Madrid, Espasa-Calpe, 1969. 
, Diálogo de Mercurio y Carón, Madrid, Castalia, 1993.

Vidal, Silvina, "Una revisione delle tesi di André Chastel su alcune rappresentazioni contemporanee del Sacco di Roma (1527)”, Archivio Storico Italiano, núm. 644, abril-junio 2015, pp. 275-312.

Villacañas Berlanga, José Luis, ¿Qué imperio? Un ensayo polémico sobre Carlos Vy la España imperial, Córdoba, Almuzara, 2008.

Webb Wheeler, Benjamin, "The Papacy and Hispanic Interstate Relations, 11951212", The Catholic Historical Review, vol. 13, núm. 1, abril 1927, pp. 29-38.

Yates, Frances A., Astraea: The Imperial Theme in the Sixteenth Century, London. Pimlico, 1993. 